\title{
Life Cycle Assessment of the Energy Independence and Security Act of 2007: Ethanol - Global Warming Potential and Environmental Emissions
}

Conference Paper NREL/CP-6A2-45805 July 2009

Garvin A. Heath, David D. Hsu, Daniel Inman, Andy Aden, and Margaret K. Mann

Presented at the American Society of Mechanical Engineers (ASME) Third International Conference on Energy Sustainability San Francisco, California

July 19-23, 2009 


\section{NOTICE}

The submitted manuscript has been offered by an employee of the Alliance for Sustainable Energy, LLC (ASE), a contractor of the US Government under Contract No. DE-AC36-08-GO28308. Accordingly, the US Government and ASE retain a nonexclusive royalty-free license to publish or reproduce the published form of this contribution, or allow others to do so, for US Government purposes.

This report was prepared as an account of work sponsored by an agency of the United States government. Neither the United States government nor any agency thereof, nor any of their employees, makes any warranty, express or implied, or assumes any legal liability or responsibility for the accuracy, completeness, or usefulness of any information, apparatus, product, or process disclosed, or represents that its use would not infringe privately owned rights. Reference herein to any specific commercial product, process, or service by trade name, trademark, manufacturer, or otherwise does not necessarily constitute or imply its endorsement, recommendation, or favoring by the United States government or any agency thereof. The views and opinions of authors expressed herein do not necessarily state or reflect those of the United States government or any agency thereof.

Available electronically at http://www.osti.gov/bridge

Available for a processing fee to U.S. Department of Energy and its contractors, in paper, from:

U.S. Department of Energy

Office of Scientific and Technical Information

P.O. Box 62

Oak Ridge, TN 37831-0062

phone: 865.576 .8401

fax: 865.576 .5728

email: mailto:reports@adonis.osti.gov

Available for sale to the public, in paper, from:

U.S. Department of Commerce

National Technical Information Service

5285 Port Royal Road

Springfield, VA 22161

phone: 800.553.6847

fax: 703.605.6900

email: orders@ntis.fedworld.gov

online ordering: http://www.ntis.gov/ordering.htm 


\title{
LIFE CYCLE ASSESSMENT OF THE ENERGY INDEPENDENCE AND SECURITY ACT OF 2007: ETHANOL - GLOBAL WARMING POTENTIAL AND ENVIRONMENTAL EMISSIONS
}

\author{
Garvin A. Heath \\ Strategic Energy Analysis Center, National Renewable Energy Laboratory \\ Golden, Colorado, USA \\ David D. Hsu \\ Strategic Energy Analysis Center, National Renewable Energy Laboratory \\ Golden, Colorado, USA \\ Daniel Inman \\ National Bioenergy Center, National Renewable Energy Laboratory \\ Golden, Colorado, USA \\ Andy Aden \\ National Bioenergy, National Renewable Energy Laboratory \\ Golden, Colorado, USA \\ Margaret K. Mann \\ Strategic Energy Analysis Center, National Renewable Energy Laboratory \\ Golden, Colorado, USA
}

\section{INTRODUCTION}

Strategies to reduce the dependence of the United States on foreign oil, increase the use of renewable energy, and lessen the contribution to global warming have received significant attention. National adoption of such strategies could significantly impact America's economy and security as well as global climate change. The Energy Independence and Security Act of 2007 (EISA) mandates specific renewable energy market penetration targets for the year 2022 [1]. For liquid transportation fuels, the 2022 EISA mandate is 36 billion gallons per year (bgy) of biofuel, of which 21 bgy must come from feedstocks other than corn starch. Despite this legal mandate for renewable biofuels, many questions remain unanswered with regard to the potential environmental effects of such a large increase in the production and use of biofuels. In addition to specifying volumetric standards for these renewable fuels, EISA establishes greenhouse gas mitigation standards. The objective of this study is to use life cycle assessment (LCA) to evaluate the global warming potential (GWP), water use, and net energy value (NEV) associated with the EISA-mandated 16 bgy cellulosic biofuels target, which is assumed in this study to be met by cellulosic-based ethanol, and the EISA-mandated 15 bgy conventional corn ethanol target. Specifically, this study compares, on a per-kilometer-driven basis, the GWP, water use, and NEV for the year 2022 for several biomass feedstocks.

\section{METHODS}

Life cycle assessment is the method used to determine the global warming potential of the production and use of the fuel. LCA is a way of looking at a process from "cradle to grave." In other words, LCA tracks the net emissions and non-renewable energy and non-renewable materials that go into not only the main process of interest, but also processes that go into intermediate feedstocks associated with that process. Life cycle assessment methodology has been codified by the International Standards Organization (ISO 14040 and 14044) [2], and efforts have been made in this study to adhere to ISO standards, which include stakeholder reviews.

\section{Scope}

The 2022 scenario includes 15 billion gallons of corn ethanol, assumed to be produced solely by corn dry mills, and 16 billion gallons of ethanol from cellulosic feedstocks. The cellulosic feedstocks considered are corn stover, wheat straw, switchgrass, and forest residues. This study is done on a national level. Most data used are national averages and will not be indicative of one particular region of the country. All ethanol is assumed to be produced in the continental United States, precluding the need for imports. All energy flows associated with production, distribution, and use of ethanol are tabulated. Avoided products, such as the co-product of the corn ethanol process, which is used as a substitute for animal feed, are 
included. In addition, product displacement, such as the removal of corn stover for ethanol resulting in lost winter grazing feed, is also included. Impacts from the manufacture and construction of infrastructure attributable to EISA is amortized over the lifetime of the infrastructure. However, the impacts of land use converted as an indirect result of land used for biofuels biomass production, so-called "indirect land use" [3] is not included in this phase of the study. The science behind indirect land use is still not settled, and when a stronger scientific consensus on this issue emerges, this LCA will incorporate those results.

The product stages in this life cycle are biomass production, harvest, pre-processing, transportation to conversion plant, fuel deliver, and end use. Modules were developed in SimaPro v.7.1.8 (Product Ecology Consultants, Amersfoort, The Netherlands) using the Ecolnvent v.2.0 (Swiss Center for Life Cycle Inventories, Duebendorf, Switzerland) database for materials and processes that were not user-generated.

\section{Feedstock production and harvest}

Feedstock production and harvest includes all activities and infrastructure required to establish and grow the biomass, and then harvest the feedstock so it is available to ship for preprocessing.

Corn and corn stover production is modeled using data from the USDA National Agricultural Statistics Service (USDA-NASS) and standard US corn production practices. Corn grain yield is projected to the year 2022 using least squares regression analysis of historical US average corn production data from 1964 to 2006 ; a $95 \%$ prediction interval $(\mathrm{PI})$ of 9.5 to $12.4 \mathrm{Mg} \mathrm{ha}^{-1}$ is used [4].

Total stover produced was estimated using a harvest index $(\mathrm{HI})$ of $0.5(\mathrm{HI}=$ weight of corn grain / (weight of corn grain + weight of stover) [5]. However, harvested stover is based on a removal rate of $30 \%$ of the total stover [6]. This removal rate does not account for soil carbon maintenance, and is therefore likely an optimistic estimate of a national average stover removal rate.

Because corn stover is a co-product of corn production, the environmental burdens associated with the whole system (i.e., grain and stover production) should be shared between the two. For this study, environmental burdens between corn grain and corn stover are allocated using an incremental allocation. The incremental allocation is conceptually the simplest and involves assigning only the environmental burdens that are directly a result of stover harvesting activities to the stover. Several other allocation methods were tested including ones based proportionally on mass, energy content, and ethanol yield, but the selection of an allocation method was not found to significantly impact the results.

Wheat and wheat straw production are modeled similarly to corn and corn stover. Two wheat systems are modeled: winter wheat and spring wheat. The two systems are similar with regard to inputs and management practices. Wheat production is modeled using data from the USDA National Agricultural Statistics Service (USDA-NASS) and standard US wheat production practices for both winter and spring wheat.
Switchgrass production are projected based on a series of papers from on-farm studies in North Dakota, South Dakota, Nebraska, and Minnesota [7-9]. Since switchgrass production does not involve any co-products, all environmental burdens are assigned to switchgrass.

Forest residue is modeled as a co-product of whole-tree timber harvesting operations. For the purpose of this study, forest residue is defined as non-merchantable woody material made available through standard timber harvesting operations. This includes non-merchantable stem, crown, and pre-commercial thinnings. Whole-tree harvest is the predominant timber harvesting method practiced in the US and involves harvesting the entire tree, less the stump and roots, and transporting it to the landing where it is processed into merchantable portions (i.e., sawlogs and pulpwood) [10]. Life cycle inventory (LCI) data for US logging practices are developed by the Consortium for Research on Renewable Industrial Materials.

Corn grain harvest consists of combine harvesting, transport to a storage facility. All processes are taken from Ecolnvent [11]. Harvest steps for the herbaceous feedstocks are modeled based on the Idaho National Laboratory (INL) feedstock delivery design report [12].

\section{Preprocessing}

The process of preprocessing biomass in 2022 is modeled based on the INL feedstock delivery design report [12]. That report projects out a feedstock supply system that would provide a uniform feedstock prior to arriving at the biorefinery conversion facility. In the "Advanced Uniform-Format Feedstock Supply System," the biomass is separated from any grain, ground, and stored at a preprocessing facility. This ground biomass is then delivered to the plant gate, avoiding feedstock processing at the biorefinery. This LCA includes the assumption that this would be the feedstock supply system in 2022.

Transport of the harvested feedstock to the preprocessing facility, located some distance from the farm, is modeled in this section. Transport of the corn grain is divided between wagon and a semi-truck transport, with different distances for each mode [13].

\section{Feedstock transport}

Feedstock is transported from the storage facility to the conversion facility. The mode of transportation is broken down across truck, rail, and barge based on a USDA report [14]. Distances are based on the INL design report, Carnegie Mellon University Modeling, and the USDA [14-16].

\section{Conversion technology}

While no commercial-scale cellulosic ethanol facilities exist today, conceptual designs for these facilities are documented in NREL design reports. Production of ethanol by biochemical route (specifically through dilute acid pretreatment, enzymatic hydrolysis, and fermentation) is described in a report by Aden et al. [17]. Production of ethanol via a thermochemical route (through indirect gasification and mixed alcohol synthesis) is documented in a report by Phillips et al. [18]. Both these designs were constructed for a future scenario when technological improvements would make cellulosic ethanol cost competitive. 
For the 2022 scenario in this LCA, these conceptual designs are used as the basis for cellulosic ethanol conversion facilities.

This study employs the simplifying assumption that the herbaceous feedstocks (corn stover, wheat straw, and switchgrass) are converted through a biochemical fermentation pathway to ethanol while the woody feedstock (forest residues) is converted through a thermochemical gasification pathway to ethanol.

Conversion processes are based on models developed using AspenPlus $^{\mathrm{TM}}$ (Aspen Technology Inc., Burlington, Massachusetts, USA) software. For sensitivity analysis in this LCA, the models are run for different parameter values and linear regressions are developed for inputs and outputs of the processes.

Corn dry mill mass balances are based on a 2007 version of the corn dry mill AspenPlus ${ }^{\mathrm{TM}}$ model used in a joint 2000 report between the U.S. Department of Agriculture and NREL [19]. The energy input for the corn dry mill is based on a study by Mueller of process heat and electricity for corn dry mills [20]. The 2022 version of the corn dry mill is based on the projection of process heat and electricity mix from the Mueller study along with increased ethanol yields from Argonne National Laboratory's GREET (Greenhouse gases, Regulated Emissions, and Energy use in Transportation) 1.8b (Argonne National Laboratory, Argonne, Illinois, USA) model [21].

\section{Ethanol distribution}

Ethanol is distributed from the conversion plant to a blending terminal, where it is blended with gasoline to form E85 transportation fuel. This fuel is then transported to the refueling station. The transportation modal allocation between truck, barge, and rail is based on studies by USDA and Reynolds [14, 22]. Gasoline used for blending in 2022 is assumed to be the same as gasoline in 2005, since while unconventional crude sources, such as tar sands, are expected to increase in production by 2022 , the impact is still small compared to the overall crude supply. Infrastructure needed for E85 delivery is included.

\section{End use}

Vehicle operation is based on evaluating vehicle types (car, light duty truck 1 , light duty truck 2) from the GREET model [21]. This study considers the use of E85 in a flex-fuel vehicle. Other life stages of the vehicle, such as vehicle manufacture, servicing, and end-of-life are not included.

\section{RESULTS}

A comparison of the GWP of the E85 fuel in 2022 resulting from the different feedstocks is shown in FIGURE 1. The graph shows the GWP calculated in carbon dioxide equivalents per vehicle kilometer traveled. The results span the entire life cycle of the fuel, from the production of the biomass to the end use in a vehicle.

Each feedstock in FIGURE 1 show the contribution of each process stage. The feedstock uptake portion of each bar is negative because each feedstock consumes carbon dioxide from the atmosphere.
Because this LCA includes the carbon dioxide taken in by the feedstock (biogenic carbon dioxide), the conversion stage has a large impact on global warming potential. However, this is mostly biogenic carbon dioxide and not fossil carbon dioxide. End use also has a significant impact on global warming potential. Similar to the conversion stage, the end use stage also includes the release of biogenic carbon dioxide from the combustion of ethanol. Since this study is on E85, the end use also includes combustion of the gasoline portion of the fuel. Feedstock production and harvesting for switchgrass has a larger impact than with other feedstocks because switchgrass harvest efficiency is 80 percent and the switchgrass that is not harvested decomposes to produce carbon dioxide [23].


FIGURE 1. GWP FOR 2022 E85 ACROSS FEEDSTOCKS

Water use for the different feedstocks for E85 ethanol are shown in FIGURE 2. Conversion shows a negative water use for corn stover, switchgrass, and wheat straw because electricity from lignin is produced, displacing grid electricity and any water use used in electricity generation. Corn shows negative water use because corn dry mills produce distillers dried grains with soluble (DDGS), which substitute for animal feed: namely corn, soy, and urea. The displacement of DDGS avoids the water used in producing conventional animal feed. Water use in the preprocessing stage for corn stover, switchgrass, and wheat straw is significant because electricity is used in drying, grinding, and dust collection [16]. The water use in this life cycle is not the same as consumptive water use, which may be more relevant when considering water sustainability issues. 
Corn shows the largest amount of water use, the bulk of it related to feedstock production. Under the incremental allocation method employed in this study, the amount of irrigated water is allocated entirely to grain and not to residue. Water use is extremely sensitive to the choice of allocation method. While there remains considerable debate in the LCA literature as to how to assign impacts to co-products, since agricultural residues would not likely be the main (most highly valued) agricultural product from a multi-product agricultural system, the incremental allocation method would appear justified. However, if farmers decided to grow a feedstock partly based on residue value instead of just based on grain value, the use of the productpurpose allocation method should be re-evaluated and sustainability conclusions regarding water should be revisited.

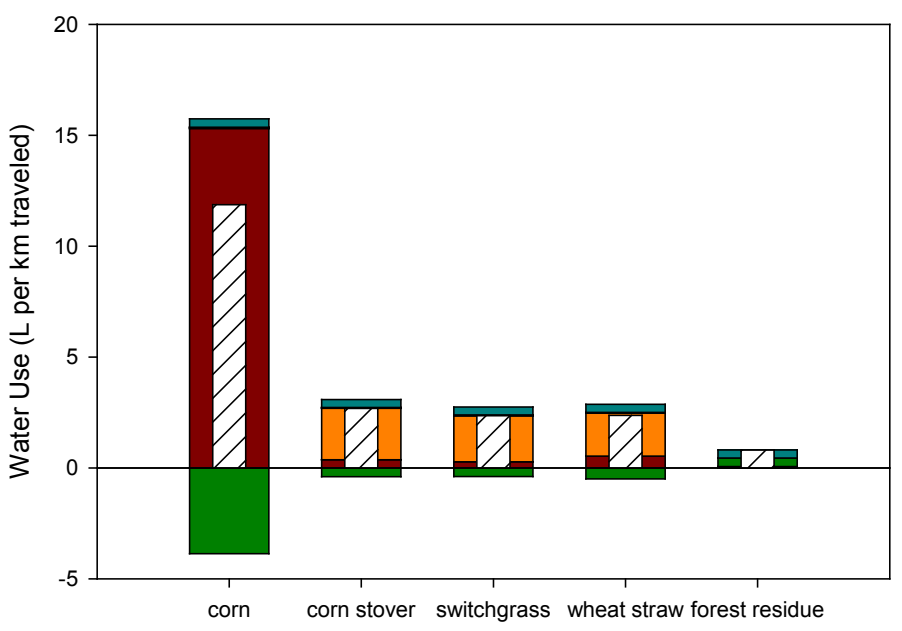

$$
\begin{array}{|l|}
\hline \\
\text { Feedstock production and harvesting } \\
\text { Preprocessing } \\
\text { Feedstock transportation } \\
\text { Conversion } \\
\text { Distribution } \\
\text { Vehicle operation }
\end{array}
$$

$\square \square$ Net Water

$Z / \mathrm{Net}$ W

FIGURE 2. TOTAL LIFE CYCLE WATER USE FOR 2022 E85

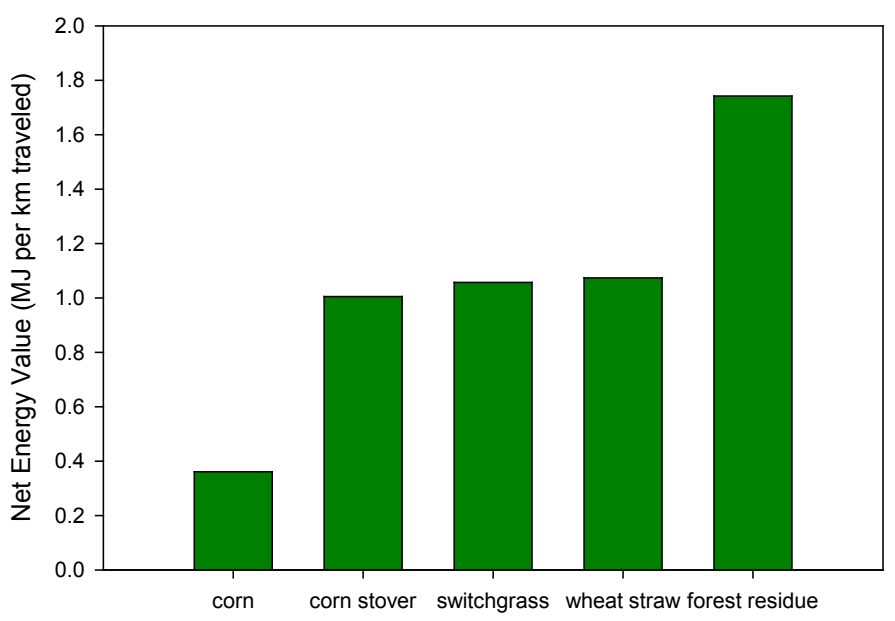

FIGURE 3. NET ENERGY VALUE FOR 2022 E85

The net energy value for E85 for the different feedstocks is shown in FIGURE 3. Net energy value is calculated by summing up the lower heating values of the products (ethanol, gasoline, and mixed alcohols) and subtracting the input energies from fossil, nuclear, and renewable sources. The energy values of avoided products such as DDGS and electricity are not included since the life cycle already takes into accounted avoided fossil and other input energies.

Almost all the input energy come from fossil sources, and the breakdown of the fossil energy is shown in FIGURE 4. Distribution constitutes a large portion for each feedstock because distribution includes the blending of gasoline and the fossil input involved in the production of gasoline. Corn stover, switchgrass, and wheat straw have no fossil energy input for conversion because the conversion refineries generate their own electricity. 




\begin{tabular}{|l|}
\hline Feedstock production and harvesting \\
Preprocessing \\
Feedstock transportation \\
Conversion \\
Distribution \\
End use
\end{tabular}

FIGURE 4. FOSSIL ENERGY FOR 2022 E85

Global warming potential for all feedstocks for E85 are better than gasoline in 2005, the standard set in EISA. E85 from corn ethanol in 2022 is over 40 percent better in GWP than gasoline in 2005. Corn grain ethanol in 2022 has fewer carbon dioxide emissions as biomass boilers, biomass combined heat and power, and integrated biogas systems make up a larger portion of the energy feedstock for corn dry mills. In addition, corn dry mills are projected to increase in efficiency.

Cellulosic ethanol in 2022 also has life cycle carbon dioxideequivalent emissions than gasoline. The feedstock used for cellulosic feedstock makes a significant impact on the global warming potential of ethanol. Among herbaceous cellulosic feedstocks, greenhouse gas emissions are all about the same, with wheat straw being the least carbon intensive. Wheat straw, as a residue, has fewer biomass production-related inputs compared to switchgrass, and unlike corn stover, wheat straw does not serve as a feed supplement and thus does not require a product to displace the loss of wheat straw. Forest residue has a higher global warming potential because of the conversion process. From a life cycle water and net energy value perspective, cellulosic feedstocks are more sustainable than corn ethanol in 2022.

\section{CONCLUSION}

A life cycle model has been developed to analyze the climate impact of the renewable fuel standards set by EISA. Projected 2022 E85 from corn and cellulosic feedstocks show improved life cycle greenhouse gas emissions over gasoline. This model provides a framework to better understand the major factors affecting greenhouse gas emissions related to the 2022 biofuels targets of EISA. Sensitivity and uncertainty analysis will be included at a later stage of this study as will indirect land use impacts. Current estimates of indirect land use have varied by a factor of four [24]. When greater scientific consensus is reached on this factor, the indirect land use impact can be included in this study.

\section{REFERENCES}

1. United States Government, Energy Independence and Security Act of 2007, in Public Law 110-140. 2007. p. 311.

2. Finkbeiner, M., et al., The new international standards for life cycle assessment: ISO 14040 and ISO 14044. International Journal of Life Cycle Assessment, 2006. 11(2): p. 80-85.

3. Searchinger, T., et al., Use of U.S. Croplands for Biofuels Increases Greenhouse Gases Through Emissions From Land-Use Change. Science, 2008: p. 1-7.

4. USDA-NASS, National agricultural statistics service. Quick stats. . 2006.

5. Donald, C.M., and Hamblin, J., The biological yield and harvest index of cereals as agronomic and plant breeding criteria. Advances in Agronomy, 1976. 28: p. 361-405.

6. Graham, R.L., et al., Current and potential US corn stover supplies. Agronomy Journal, 2007. 99(1): p. 111.

7. Vogel, K.P., et al., Switchgrass Biomass Production in the Midwest USA: Harvest and Nitrogen Management. Agronomy Journal, 2002. 94: p. 413-420.

8. Vogel, K.P., et al., Winter Survival in Switchgrass Populations Bred for High IVDMD. Crop Science, 2002(42): p. 1857-1862.

9. Vogle, K.P., Genetic Improvement of Switchgrass and Other Herbaceous Plants for Use as Biomass Fuel Feedstock, DOE, Editor. 2000: Oak Ridge, TN. p. 52.

10. Leinonen, A., Harvesting technology of forest residues for fuel in the USA and Finland, in Espoo 2004. 2004, VTT Processes.

11. Nemecek, T. and T. Kägi, Life Cycle Inventories of Agricultural Production Systems Data 2.0, in ecoinvent report 2007, Swiss Centre for Life Cycle Inventories: Zürich and Dübendorf, Switzerland.

12. Hess, J.R., et al., Uniform-format solid feedstock supply system. 2009, Idaho National Laboratory: Idaho Falls, Idaho.

13. Yu, T.-H. and C.E. Hart, The 2006/07 lowa Grain and Biofuel Flow Study: A Survey Report. 2008, Center for Agricultural and Rural Development, lowa State University: Ames, lowa.

14. Denicoff, M.R., Ethanol Transportation Backgrounder: Expansion of U.S. Corn-based Ethanol from the Agricultural Transportation Perspective. 2007, United States Department of Agriculture. p. 1-29.

15. Wakeley, H.L., Alternative Transportation Fuels: Infrastructure Requirements and Environmental Impacts for Ethanol and Hydrogen, in Department of Civil and Environmental Engineering. 2008, Carnegie Mellon University: Pittsburgh, PA. p. 195. 
16. INL, Uniform-Format Feedstock Supply System Design for Lignocellulosic Biomass: DRAFT. 2009, Idaho National Laboratory: Idaho Falls, ID. p. 134.

17. Aden, A., et al., Lignocellulosic Biomass to Ethanol Process Design and Economics Utilizing Co-Current Dilute Acid Prehydrolysis and Enzymatic Hydrolysis for Corn Stover. 2002, National Renewable Energy Laboratory: Golden, CO.

18. Phillips, S., et al., Thermochemical Ethanol via Indirect Gasification and Mixed Alcohol Synthesis of Lignocellulosic Biomass. 2007, National Renewable Energy Laboratory: Golden, CO.

19. McAloon, A., et al., Determining the Cost of Producing Ethanol from Corn Starch and Lignocellulosic Feedstocks. 2000, U.S. Department of Agriculture National Renewable Energy Laboratory: Golden, CO.

20. Mueller, S., An analysis of the projected energy use of future dry mill corn ethanol plants (2010-2030). 2007, University of Illinois at Chicago: Chicago, IL.

21. Wang, M., The Greenhouse Gases, Regulated Emissions, and Energy Use in Transportation (GREET) Model 1.8b. 2008, Argonne National Laboratory.

22. Reynolds, R.E., Ethanol's Potential Contribution to U.S. Transportation Fuel Pool. 2006, Downstream Alternatives Inc.

23. Bransby, D. Energy balance and energy efficiency of bioenergy. AFC Cooperative Farming News 2006 January 2006 [cited 2009 May 11]; Available from: http://www.alafarmnews.com/0905archive/0905bioener gy.htm.

24. Tyner, W., F. Taheripour, and U. Baldos. Land use carbon emissions due to the U.S. ethanol program. 2009 January 26; Available from: http://www.agecon.purdue.edu/staff/tyner/papers/Purdu e\%20Wally\%20Farzad\%20Uris.pdf. 


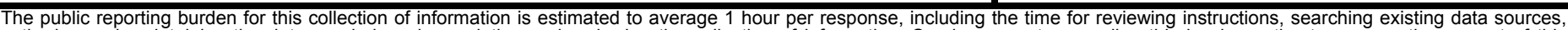

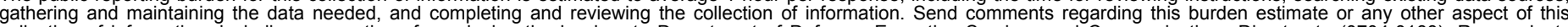

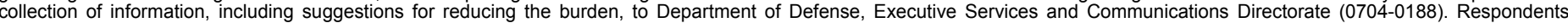

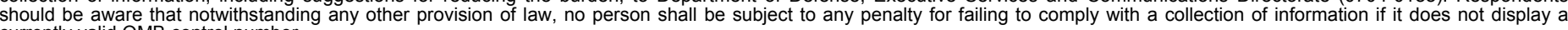
currently valid OMB control number.

PLEASE DO NOT RETURN YOUR FORM TO THE ABOVE ORGANIZATION.

\begin{tabular}{ll|l|l|l} 
1. & REPORT DATE (DD-MM-YYYY) & 2. REPORT TYPE & DATES COVERED (FrOm - TO)
\end{tabular} July 2009

Conference Paper

4. TITLE AND SUBTITLE

Life Cycle Assessment of the Energy Independence and Security Act of 2007: Ethanol - Global Warming Potential and Environmental Emissions

6. AUTHOR(S)

G.A. Heath, D.D. Hsu, D. Inman, A. Aden, and M.K. Mann 5a. CONTRACT NUMBER

DE-AC36-08-GO28308

5b. GRANT NUMBER

5c. PROGRAM ELEMENT NUMBER

5d. PROJECT NUMBER

NREL/CP-6A2-45805

5e. TASK NUMBER

BB07.7511

5f. WORK UNIT NUMBER

7. PERFORMING ORGANIZATION NAME(S) AND ADDRESS(ES)

National Renewable Energy Laboratory

8. PERFORMING ORGANIZATION REPORT NUMBER

1617 Cole Blvd.

NREL/CP-6A2-45805

Golden, CO 80401-3393

9. SPONSORING/MONITORING AGENCY NAME(S) AND ADDRESS(ES)

10. SPONSOR/MONITOR'S ACRONYM(S) NREL

11. SPONSORING/MONITORING AGENCY REPORT NUMBER

\section{DISTRIBUTION AVAILABILITY STATEMENT}

National Technical Information Service

U.S. Department of Commerce

5285 Port Royal Road

Springfield, VA 22161

\section{SUPPLEMENTARY NOTES}

\section{ABSTRACT (Maximum 200 Words)}

Strategies to reduce the dependence of the United States on foreign oil, increase the use of renewable energy, and lessen the contribution to global warming have received significant attention. National adoption of such strategies could significantly impact America's economy and security as well as global climate change. The Energy Independence and Security Act of 2007 (EISA) mandates specific renewable energy market penetration targets for the year 2022 [1]. For liquid transportation fuels, the 2022 EISA mandate is 36 billion gallons per year (bgy) of biofuel, of which 21 bgy must come from feedstocks other than corn starch. Despite this legal mandate for renewable biofuels, many questions remain unanswered with regard to the potential environmental effects of such a large increase in the production and use of biofuels. In addition to specifying volumetric standards for these renewable fuels, EISA establishes greenhouse gas mitigation standards. The objective of this study is to use life cycle assessment (LCA) to evaluate the global warming potential (GWP), water use, and net energy value (NEV) associated with the EISA-mandated 16 bgy cellulosic biofuels target, which is assumed in this study to be met by cellulosic-based ethanol, and the EISA-mandated 15 bgy conventional corn ethanol target. Specifically, this study compares, on a per-kilometer-driven basis, the GWP, water use, and NEV for the year 2022 for several biomass feedstocks.

\section{SUBJECT TERMS}

life-cycle assessment; ethanol; global warming potential; Energy Independence and Security Act; DISA; greenhouse gas; biofuels; transportation

\section{SECURITY CLASSIFICATION OF:}

\section{a. REPORT}

Unclassified

\section{b. ABSTRACT \\ c. THIS PAGE}

Unclassified

\begin{tabular}{l|l} 
17. LIMITATION & 18. $\begin{array}{l}\text { NUMBER } \\
\text { OF ABSTRACT } \\
\text { OF PAGES } \\
\text { UL }\end{array}$
\end{tabular}

19a. NAME OF RESPONSIBLE PERSON

19b. TELEPHONE NUMBER (Include area code) 